\title{
$\angle 8$ Research Square \\ Epidemiological Study of Unintentional Childhood Injuries in a Rural and Urban Area of Mangaluru Taluk, Dakshina Kannada District, Karnataka State, India
}

Abhay S Nirgude

Yenepoya Medical College

Mubeena Haleema ( $\nabla$ mubeenahaleema@gmail.com )

Yenepoya Medical College https://orcid.org/0000-0003-4016-7289

\section{Original Contribution}

Keywords: Unintentional injury, risk factors, Epidemiological study, childhood injuries

Posted Date: February 15th, 2022

DOI: https://doi.org/10.21203/rs.3.rs-1316489/v1

License: (a) (i) This work is licensed under a Creative Commons Attribution 4.0 International License. Read

Full License 


\section{Abstract}

\section{Background:}

Worldwide injury \& violence is most important cause of death in children, every year it causes death in approximately 950000 children and youngsters who are under the age group of 18 years of age. Ninety percent of it is caused by unintentional injuries.

\section{Methods:}

This study was conducted with the aim to find the period prevalence and factors associated with unintentional childhood injuries. The study was conducted in rural and urban field practice area of a private medical College, Mangaluru taluk.. Community based cross sectional study was conducted by enrolling 400 children (0-18 years) from rural area and 500 from urban during July 2016 to October 2018. Multistage simple random sampling method was followed to select the participants. Source of data was Mother/Father. Predesigned pretested validated structured questionnaire was used to collect the data.

\section{Results:}

Period prevalence of childhood injury was $67(16.8 \%)$ in rural area and $93(18.6 \%)$ in urban area. In both area fall was most common cause of injury. Factors which were found to be protective against injury were male child, children of working women in rural area and in urban area it was children belonging to lower and middle socio-economic status, child with 1 sibling. Usage of protective gears while driving was reported by majority of subjects. Almost one third of the children had risk factors for burn at home. However risk factors for sharp injury and animal bite was not found in majority of the children. Environmental risk factors for falls were unprotected roof/balcony/staircase, unsafe equipment/ deep ditches in playground. In both areas, risk factors for fall were significantly associated with fall.

\section{Conclusions:}

Magnitude of unintentional childhood injuries was similar in rural and urban areas, in both areas majority of the participants had fall as a cause of injury. Varied risk factors for injury were found in both areas. Injury prevention, risk reduction should be part of school curriculum and school health programme. Parents should be sensitized about the common type of injury, risk factors and its prevention

\section{Background:}

Worldwide injury \& violence is most important cause of death in children, every year it causes death in approximately 950000 children and youngsters who are under the age group of 18 years of age. Ninety percent of it is caused by unintentional injuries (Peden et al. 2008). Childhood injury is an important aspect in child health. Childhood injury evaluation should be considered while developing child health policy at different levels (Renu and George 2014). It is estimated that $55 \%$ of global injury burden mortality is seen in South East Asia and Western pacific regions of World health organisation among the populations that are under the age group of 20 years (World Health Organisation 2010). The causes of injuries include drowning, 
transport related, burns, falls, poisoning etc. Though injury being a major health issue among children, it is not addressed properly (World Health Organisation 2010). During the year 2005, there was an estimated death of 6, 48,000 people due to unintentional injury (Jagnoor et al.2012). Detailed work on child injury in low and middle income countries is began more recently and is now indicating its priorities for prevention (Peden et al. 2008). There is dearth of data on childhood injuries in India. For each area of child injury there are proven ways to reduce both the likelihood and severity of injury (Peden et al. 2008; Shriyan et al. 2014). For effective intervention and prevention there is a need to assess the burden, causes and consequences of unintentional injuries (Alamgir et al. 2012; Ray et al.2012). This study was conducted to determine the magnitude of unintentional injuries among children and to learn the epidemiological factors associated with it, which will help in developing preventive measures. This article describes few of the injury profile and focuses on epidemiological factors associated with childhood injuries.

\section{Methods:}

The study was conducted in rural and urban field practice area of a Private Medical College, Mangaluru taluk, Karnataka state of India. Out of the 4 villages in rural and 3 wards in urban area one village and one ward was selected respectively by lottery method. Selected rural area had total population of 4941 with 905 households; population under 18 years is 1926. Selected urban area had total population of 6250 with 1148 households; population under 18 years is 2437.

Community based cross sectional study was conducted during July 2016 to October 2018 . Study population being Children aged 0-18 years residing in the study area. Source of data was Mother/Father. Inclusion criteria being children less than 18 years with unintentional injuries in the past 1 year. Exclusion criteria were Intentional injuries, injuries due to violence, children with epilepsy, fatal injuries.

Based on pilot study it was found that prevalence of unintentional injuries among children was $18 \%$ and $25 \%$ in rural and urban area respectively. With and expected response rate of $60 \%, 5 \%$ absolute precision and $95 \%$ confidence, sample size calculated was 378 (rounded to 400) for rural area and 481 (rounded to 500) for urban area. Unintentional injury was defined as Injury among children which resulted in seeking of medical care or absence of school or inability to do normal physical activity for a duration of minimum of one day in the past one year in a child aged 0-18 years (Rahman et al.2005; Chowdhury et al.2009).

Sampling method: Multistage simple random sampling method was used. In order to collect data from 400 children a total of 200 households were selected by simple random sampling method in rural area. In order to collect data from 500 children a total of 250 households were selected by simple random sampling method in urban area (Department of Health and Family welfare, India 2017) (Fig. 1).

Study tool: Internal reliability of the questionnaire was checked. The reliability was found to be very good, Cronbach's alpha score was $>0.7$ in both study area. The questionnaire was given to 4 subject expert for content and consensual validity.

Predesigned pretested validated structured questionnaire was developed on the basis of similar studies (Rahman et al.2005, World Health Organisation 2010; Chowdhury et al.2009) world injury report 2008 (Peden 
et al. 2008), Haddon matrix (Simon 2002), pilot study and based on local cultural \& social practice. Study questionnaire consisted of three parts: that is Socio-demographic profile, Injury profile, Epidemiological factors.

Method of data collection: Information was collected by one to one interview method from mother, if mother was not available father was the next respondent, if both are not available second visit was done. If on second visit parents were not available then that child was not included in the study.

This study included injuries caused by sharp objects, falls, poisoning, Road traffic injuries, burns/fire, injuries caused by animals, drowning, electric shocks, suffocation (Peden et al. 2008).

\section{Details of data tabulation and statistical analysis employed:}

Data was analyzed using statistical package for social science (SPSS 23). Descriptive statistic was reported as Median and inter-quartile range for continuous variables and frequency and proportion for categorical variable. Inferential statistics: chi-square test was used to analyze bivaraite analysis. Multivariate Binary logistic regression was performed and unadjusted and adjusted odds ratio with $95 \%$ Confidence interval and p-value was reported.

\section{Results:}

\section{Socio-demographic profile:}

In rural area $37 \%$ of study participants were in the age group of $<5$ years and in urban area $37 \%$ of study participants were in the age group of 11-15 years. More than half of study participants were male in rural area $(64.8 \%)$ and urban area (54.6\%). Socio-economic status in majority of study participants was middle $(36 \%)$ and lower middle class (44\%) in rural area; and in urban area it was middle (45.6\%) and lower middle class (36\%) (Table 1). Median age of study participant in rural area was 8 (13-4) years and in urban area it was $9(12-5)$ years (Table 2$)$.

\section{Brief description of Injury profile:}

Period prevalence of childhood injury was 67(16.8\%) in rural area and 93(18.6\%) in urban area. In rural area most common cause of injury was fall (59.7\%), followed by injury due to sharp objects (13.4\%), burn (11.94\%), road traffic injuries (10.4\%) and animal bite (4.4\%). In urban area most common cause of injury was fall (60.2\%), followed by burn (15\%), injury due to sharp objects (12.9\%), road traffic injuries (9.6\%), and animal bite (2.15\%) (Table 3).

Majority of children with childhood injuries had parental/caregivers supervision at home in rural area $(85.1 \%)$ and urban area (83.9\%). While half of children had parental/ caregivers supervision in rural area (56.7\%) and urban area (52.7\%) (Table 4).

Among the activity at the time of injury, Sports activity was present in more than one third of the participants $[26(38.7 \%)]$ and more than half of the participants $[43(46.15 \%)]$ in rural and urban area respectively. Sports 
activity was majorly present in males [rural: $19(28.3 \%$ and urban $29(31.1 \%))$ ] than females [rural: $7(10.4 \%)$ and urban 14(15.05\%)] area (Table 5).

On analysing the association between Socio-demographic profile and unintentional injury following results were obtained

1. In rural area: Male gender [Adjusted odds ratio: $0.47(0.24-0.90)$ ( $p$ value-0.024)] and Children of working women [Adjusted odds ratio: $0.43(0.20-0.90)$ ( $p$ value-0.027)] were found to be protective factors against unitenintional childhood injuries (Table 6 given in additional file 1).

2. In urban area: Middle class [Adjusted odds ratio: 0.29(0.10-0.89) ( $p$ value-0.03)] and lower class [Adjusted odds ratio: $0.32(0.10-0.98)$ ( $p$ value-0.04)] of socio-economic status were found to be protective factors against unitenintional childhood injuries. Children with 1 sibling [Adjusted odds ratio: $0.53(0.31-0.89)$ ( $p$ value-0.01) was also found to be protective factors against unitenintional childhood injuries (Table 6 given in additional file 1).

\section{Epidemiological factors:}

On assessing risk factors for injuries such as Road traffic injuries, Fall, Burn, Sharp injury, Animal bite, it was found that majority of study participants did not have it in their immediate environment (Table 7).

Except for fall, period prevalence of other injuries was less, thus only fall variable was analyzed further to find out the association. Environmental risk factors such as unprotected roof/balcony/staircase, unsafe equipment/ deep ditches in playground were assessed. It was found that in both Rural and Urban area, risk factors for fall was significantly associated with fall (Table 8).

\section{Discussion:}

This article presents more on the epidemiological factors related to unintentional injuries among children in rural and urban area.

\section{Brief description on injury profile:}

The period prevalence of injury was $16.8 \%$ in rural area and in urban area it was $18.6 \%$. Difference in prevalence is not significant, this could be due to a reason that rural area which was studied was in periurban area and infrastructure, road connectivity, housing, education, and occupation was almost similar to that of urban area. Similar finding was reported in a study conducted in Texas (Arif et al. 2003). Among different causes on injury, fall was most common one in both areas. Similar finding was reported in studies conducted in different parts of India (urban and rural area) (Mahalakshmy et.al 2011; Parameswaran et al.2017; Bhuvaneswari et al.2018). While a study conducted in Dhaka (urban area), burn was most common cause of injury (Alamgir et al. 2012). Children engage themselves in sports, outdoor and indoor activities, most of their free time, which sometimes lead onto fall injury. On a similar note Sports activity was the most common activity noted during injury among males than females, which was also seen in a study conducted in China (Gong et al. 2021). 
Majority of children with childhood injuries had parental/caregivers supervision at home in rural area (85.1\%) and urban area (83.9\%). Similar finding was reported in studies conducted in Manipal and Darjeeling (Shriyan et al. 2014; Ray et al.2012). Though parents/caregivers supervision is present for majority of injured children, it could be possible that parents are not aware of potential injuries and its prevention methods.

\section{Factors associated with injuries:}

Socio-demographic factors such as male child, child of working mother had lesser possibility of getting injured in rural area. Two studies reported that injury outcome was associated with gender (He et al. 2014; Pant et al. 2015), while study in China did not find any association (Qiu et al. 2014). In contrast a study conducted in Pakisthan reported injury rate was higher in children of working mothers than home maker (Siddiqui at al. 2012). Gender difference with injury prevalence may also be influenced by different factors present locally, at family level, the way child is exposed to different risk factors for injury at home and outside.

In urban area, children belonging to middle and low class of socio-economic status and those children with one sibling had lesser possibility of getting injured. However according to some studies children belonging to low socioeconomic class have more chance of getting injured than upper class (Hippisley- Cox et al. 2002; Laursen and Nielsen 2008; Otters et al. 2005). While a study conducted in Japan found that there was no association between injury and socio-economic status (Sato et al. 2018). Similar finding like the present study is reported in a study where injury was less common with children with one sibling (Ray et al. 2012). This was contrast to a study conducted in Manipal, where injury was more common among children with one sibling (Shriyan et al.2014). Studies have reported that children with more than 3 siblings were found to have more injuries (Laursen and Nielsen 2008; Otters et al. 2005). Socio-economic status might influence the occurrence of injury, but it might also depend on how hazardous is child's immediate environment, whether there is adequate supervision by parents/caretaker, how risky is the child's behaviour. Presence of sibling might have outcome on both the sides that is occurrence of injury or not. But it can be influenced by the factors such as how the elder sibling, or in that case how children's are being taught on hazards of injuries, its prevention etc.

It was found that majority of children/parents/driver, followed usage of protective gears while driving in both areas. Studies has shown that usage of protective gears have reduced the occurrence of road traffic injuries (Mac Adams et al. 2018; Soori et al. 2009). Majority of the children did not have risk factors for sharp injury and animal bite in their environment.

Almost one third of the children had risk factors for burn such as storage of flammable substance at home, No separation of cooking area from living area, Stove within the reach of child at their immediate environment. A study reported that risk factors for burns were, access to active fire (19.3\%), access to fuel containers (16.25\%) unsafe system for warming water (86\%) (Bhuvaneswari et al.2018).

In the present study risk factors for fall at home, such as unsafe balcony/ staircase/ roof (urban area-22\%) and risk factors for fall at play ground such as unsafe equipment, deep ditches at play ground (rural area$26.8 \%$ ) were present. Risk factors for fall at home which were seen in majority of participants were unsafe 
staircase, unsafe balcony (Bhuvaneswari et al.2018). Environmental risk factors such as flooring, roofing, safety environment, etc. determines occurrence of fall (Gururaj 2005).

Factors such as unprotected roof/ balcony/ staircase, unsafe equipment at playground was significantly associated with fall in both areas. However a study reported that there was no significant association between unprotected stair case with fall (Bhuvaneswari et al.2018). Risk factors present in the environment of the child both at home and outside have its effect on occurrence of injury. Fall is an important and most common form of unintentional injury during childhood. Risk factors for falls are present in the immediate environment of the child which has its effect on the occurrence of the injury.

\section{Strengths and Limitation:}

Strengths: This was a community based cross sectional study, which was conducted in both rural and urban area, for a better comparison. Questionnaire used was recommended by World health organisation, which was later modified based on local needs.

Limitation: This was a cross sectional study design, thus association observed may not infer causality. This study includes the self-reporting design, which may lead to recall bias.

\section{Conclusion:}

Magnitude of unintentional childhood injuries was similar in rural and urban areas, in both areas majority of the participants had fall as a cause of injury. Varied risk factors for injury were found in both areas. Injury prevention, risk reduction should be part of school curriculum and school health programme. Parents should be sensitized about the common type of injury, risk factors and its prevention. They should also be sensitized about supervision of children at home and playground. Community health workers should do home visits; propagate importance of injury prevention and risk reduction measures. There should be further study involving stake holders, which will help in policy change.

\section{List Of Abbreviations:}

Nil

\section{Declarations:}

\section{Ethics approval and consent to participate}

Yenepoya university Institutional ethical committee approval was obtained. Written informed consent was obtained from respondents after explaining the purpose and the nature of the study. Written assent was obtained from children under the age group of 7-18years

\section{Consent for publication}

Not applicable 
Availability of data and material

The datasets used and/or analysed during the current study are available from the corresponding author on reasonable request

\section{Competing interests}

The authors declare that they have no competing interests

\section{Funding}

Authors declare that there was no funding received for conducting the study.

\section{Authors' contributions}

ASN contributed to the conception, design of the work, development of study protocol and study tools; analysis and interpretation of data; drafting manuscript. MU contributed to design of work, development of study protocol and study tools, data acquisition, analysis, interpretation of data, drafting the manuscript. Both authors have read, revised and approved the final version of the manuscript.

\section{Acknowledgements}

We would like to acknowledge Dr. Poonam R Naik, Professor and Head of the Department of Community Medicine, Faculties and Staff of the Department of Community Medicine, Yenepoya Medical College for their scholarly suggestions and all round encouragement in conduct of the study.

\section{References:}

1. Peden M, Oyegbite K, Smith O J, Hyder AA, Branche C, Rahman AKM F. World Report on Child Injury Prevention. World Health Organisation; 2008

2. Renu G, George A. Childhood Injury an Iceberg of Phenomenon. IOSR Journal of Dental and Medical Sciences. 2014;13(8):18-23.

3. World Health Organization. Profile of child injuries: selected member states in the Asia-Pacific region. WHO Regional Office for South-East Asia; 2010.

4. Jagnoor J, Suraweera W, Keay L et.al. Unintentional injury mortality in India, 2005: Nationally representative mortality survey of 1.1 million homes. BMC Public Health 2012;12:487

5. Shriyan P, Prabhu V, Aithal KS, Yadav UN, Orgochukwu MJ. Profile of unintentional injury among underfive children in coastal Karnataka, India: a cross-sectional study 2014. International Journal of Medical Science and Public Health. 2014; 3(11):1317-1319

6. Alamgir M, Mahboob S, Ahmed K S, Islam SM, Gazi S, Ahmed A. Pattern of Injuries among Children of Urban Slum Dwellers in Dhaka City: J. Dhaka National Med. Coll. Hos. 2012; 18(01): 24-28

7. Ray K,Bhattacherjee S, Akbar F, Biswas R, Banergee R, ChakbortyM.Physical injury: A profile among the municipal primary school children of Siliguri, Darjeeling District. Indian J Public Health 2012;56(1):49-52 
8. Rahman A, Rahman AKMF, Shafinaz S, Linnan M. Bangladesh Health and Injury Survey Report on Children. Government of the People's Republic of Bangladesh : 2005

9. Chowdhury SM, Rahman A, Mashreky SR, Giashuddin SM, Svanström L, Hörte LG, Rahman F. The horizon of unintentional injuries among children in lowincome setting: an overview from Bangladesh health and injury survey. Journal of environmental and public health. 2009

10. India. Department of Health and Family Welfare. National family health Survey [document on internet].. http://rchiips.org/nfhs/. Accessed 22 Feb 2017.

11. World health organisation. Training for the health sector: unintentional childhood injuries. Children's health and environment:2010

12. Simon RM. Using the Haddon matrix to identify strategies to prevent play ground injuries. Institute of Public Health of Slovenia. https://nanopdf.com/download/using-the-haddon-matrix-for-preventing-theinjuries_pdf. Accessed 26 Jan 2022.

13. Ahmed A, Arif A, Patti J, Tyrone F, Syed M. The Epidemiology of Unintentional Non-fatal Injuries Among Children in the South Plains/Panhandle Region of Texas. Texas J Rural Health. 2003;21:2.

14. Mahalakshmy T, Dongre AR, Kalaiselvan G. Epidemiology of childhood injuries in rural Puducherry, South India. The Indian Journal of Pediatrics. 2011 Jul;78(7):821-5

15. Parmeswaran GG, Kalaivani M, Gupta SK, Goswami AK, Nongkynrih B. Unintentional childhood injuries in urban delhi: A community-based study. Indian journal of community medicine: official publication of Indian Association of Preventive \& Social Medicine. 2017 Jan;42(1):8.

16. Bhuvaneswari N, Prasuna JG, Goel MK, Rasania SK. An epidemiological study on home injuries among children of 0-14 years in South Delhi. Indian Journal of Public Health. 2018 Jan 1;62(1):4

17. Gong H, Lu G, Ma J, Zheng J, Hu F, Liu J, Song J, Hu S, Sun L, Chen Y, Xie L. Causes and characteristics of children unintentional injuries in emergency department and its implications for prevention. Frontiers in public health. 2021;9.

18. He S, Lunnen JC, Puvanachandra P, Zia N, Hyder AA. Global childhood unintentional injury study: multisite surveillance data. American journal of public health. 2014 Mar;104(3):e79-84.

19. Pant PR, Towner E, Ellis M, Manandhar D, Pilkington P, Mytton J. Epidemiology of unintentional child injuries in the Makwanpur district of Nepal: a household survey. International journal of environmental research and public health. 2015 Nov 30;12(12):15118-28.

20. Qiu X, Wacharasin C, Deoisres W, Yu J, Zheng Q. Characteristics and predictors of home injury hazards among toddlers in Wenzhou, China: a community-based cross-sectional study. BMC public health. 2014 Dec;14(1):638

21. Siddiqui E, Ejaz K, Siddiqui U. Unintentional, paediatric domestic injury in a semi rural area of Karachi. Journal of Pakistan medical association. 2012;62(7):638

22. Hippisley-Cox J, Groom L, Kendrick D, Coupland C, Webber E, Savelyich B. Cross sectional survey of socioeconomic variations in severity and mechanism of childhood injuries in Trent 1992-7. BMJ. 2002 May;324(7346):1-6

23. Laursen B, Nielsen JW. Influence of sociodemographic factors on the risk of unintentional childhood home injuries. European Journal of public health. 2008 May 31;18(4):366-70. 
24. Otters H, Schellevis FG, Damen J, van der Wouden JC, van Suijlekom-Smit LW, Koes BW. Epidemiology of unintentional injuries in childhood: a populationbased survey in general practice. $\mathrm{Br} \mathrm{J}$ Gen Pract. 2005 Aug 1;55(517):630-3.

25. Sato N, Hagiwara Y, Ishikawa J, Akazawa K. Association of socioeconomic factors and the risk for unintentional injuries among children in Japan: a crosssectional study. BMJ open. 2018 Aug 1;8(8):e021621

26. McAdams RJ, Swidarski K, Clark RM, Roberts KJ, Yang J, Mckenzie LB. Bicycle-related injuries among children treated in US emergency departments, 2006-2015. Accident Analysis \& Prevention. 2018 Sep 30;118:11-7.

27. Soori $H$, Royanian M, Zali AR, Movahedinejad A. Road traffic injuries in Iran: the role of interventions implemented by traffic police. Traffic injury prevention. 2009 Jul 14;10(4):375-8

28. Gururaj G. Injuries in India: A national perspective. Background Papers: Burden of Disease in India Equitable Development-Healthy Future. New Delhi: National Commission on Macroeconomics and Health, Ministry of Health \& Family Welfare, Government of India. 2005 Sep:325-47

\section{Tables:}

Table 1: Socio-demographic profile of study participants 


\begin{tabular}{|c|c|c|c|}
\hline \multirow{2}{*}{\multicolumn{2}{|c|}{ Socio demographic variables }} & \multicolumn{2}{|c|}{ Frequency (\%) } \\
\hline & & $\begin{array}{l}\text { Rural } \\
\text { area } \\
(\mathrm{N}=400)\end{array}$ & $\begin{array}{l}\text { Urban area } \\
(\mathrm{N}=500)\end{array}$ \\
\hline \multirow[t]{4}{*}{ Age in years } & $<5$ & $148(37)$ & $148(29.6)$ \\
\hline & $6-10$ & $119(29.8)$ & $137(27.4)$ \\
\hline & $11-15$ & $111(27.8)$ & 186(37.2) \\
\hline & $16-18$ & $22(5.5)$ & $29(5.8)$ \\
\hline \multirow[t]{2}{*}{ Gender } & Male & $259(64.8)$ & $273(54.6)$ \\
\hline & Female & $141(35.3)$ & $227(45.4)$ \\
\hline \multirow[t]{3}{*}{ Type of family } & Nuclear & $184(46)$ & $262(52.4)$ \\
\hline & Joint & $161(40.3)$ & 190(38) \\
\hline & Three generation & $55(13.8)$ & $48(9.6)$ \\
\hline \multirow{4}{*}{$\begin{array}{l}\text { Educational status of } \\
\text { respondent }\end{array}$} & Illiterate & $58(14.5)$ & $30(6)$ \\
\hline & Primary & 116(29) & $160(32)$ \\
\hline & High school & $129(32.3)$ & 163(32.6) \\
\hline & Above high school & $97(24.2)$ & 147(29.4) \\
\hline \multirow{3}{*}{ Occupation of Father } & Unemployed & $15(3.7)$ & $16(3.2)$ \\
\hline & Skilled and Unskilled & $325(81.3)$ & $401(80.2)$ \\
\hline & Semi-professional, Professional & $60(15)$ & $83(16.6)$ \\
\hline \multirow[t]{3}{*}{ Occupation of Mother } & Home maker & $350(87.5)$ & $422(84.4)$ \\
\hline & Skilled and unskilled & $49(12.25)$ & $68(13.6)$ \\
\hline & $\begin{array}{l}\text { Semi-professional and } \\
\text { Professional }\end{array}$ & $1(0.25)$ & $10(2)$ \\
\hline \multirow[t]{5}{*}{ Socio-Economic Status ${ }^{*}$} & Upper class & $9(2.3)$ & $6(1.2)$ \\
\hline & Upper middle & $42(10.5)$ & $43(8.6)$ \\
\hline & Middle class & $144(36)$ & $228(45.6)$ \\
\hline & Lower middle class & $176(44)$ & $180(36)$ \\
\hline & Lower class & $29(7.2)$ & $43(8.6)$ \\
\hline
\end{tabular}

Legend: *as per modified BG Prasad classification 2017 
Table 2: Age distribution of study participants (Rural area $\mathrm{N}=400$ and Urban area $\mathrm{N}=500$ )

\begin{tabular}{|lll|}
\hline Age of the children & Rural area\# & Urban area\# \\
& 8(13-4) years & $9(12-5)$ years \\
\cline { 2 - 3 } Median (Q3-Q1) & Male: 8(12-4) years & Male: $9(12-5)$ years \\
\cline { 2 - 3 } & Female: 8 (13-3) years & Female: $9(12-5)$ years \\
\hline Minimum age & 6 months & 9 months \\
Maximum age & 18 years & 18 years \\
\hline
\end{tabular}

Legend: \#Age of child is projected in terms of months and years completed

Table 3: Period prevalence of unintentional injury based on cause of injury among study participants

\begin{tabular}{|lll|}
\hline \multirow{2}{*}{ Cause of injury } & \multicolumn{2}{l|}{ Frequency $(\%)$} \\
\cline { 2 - 3 } & Rural area(n=67) & Urban area (n=93) \\
\hline Road traffic injuries & $7(10.4)$ & $9(9.6)$ \\
\hline Burn & $8(11.94)$ & $14(15)$ \\
\hline Fall & $40(59.7)$ & $56(60.2)$ \\
\hline Injury due to sharp objects & $9(13.4)$ & $12(12.9)$ \\
\hline Animal bite & $3(4.4)$ & $2(2.15)$ \\
\hline
\end{tabular}

Legend: ${ }^{a}$ Period prevalence is calculated for each of the cause of injury category

Table 4: Supervision of Parents/Caregiver among children with unintentional injuries

\begin{tabular}{|lll|}
\hline & Frequency (\%) & \\
\cline { 2 - 3 } Area & $\begin{array}{l}\text { Supervision by Parents/ Caregiver at } \\
\text { home }\end{array}$ & $\begin{array}{l}\text { Supervision by Parents/Caregiver at play } \\
\text { ground }\end{array}$ \\
\hline Rural $n=67$ & $57(85.1)$ & $38(56.7)$ \\
\hline $\begin{array}{l}\text { Urban } \\
n=93\end{array}$ & $78(83.9)$ & $49(52.7)$ \\
\hline
\end{tabular}


Legend: Majority of injured children had Parental/Caregiver supervision at home in both areas

Table 5: Distribution of unintentional injuries based on activity of child at the time of injury and Gender (Rural area $n=67$ and Urban area $n=93$ )

\begin{tabular}{|llllllll|}
\hline & \multicolumn{2}{l}{ Sports activity } & \multicolumn{2}{l}{ Domestic activity } & \multicolumn{2}{ll}{ Other activity } & Total \\
\cline { 2 - 8 } & Male & Female & Male & Female & Male & Female & \\
Rurea & & & & & & & \\
Frequency (\%) & $19(28.3)$ & $7(10.4)$ & $17(25.3)$ & $4(5.9)$ & $15(22.3)$ & $5(7.4)$ & $67(100)$ \\
\hline $\begin{array}{l}\text { Urban area } \mathbf{n = 9 3} \\
\text { Frequency (\%) }\end{array}$ & & & & & & & \\
\hline
\end{tabular}

Legend: Occurrence of unintentional injuries are compared between the gender against the activity of child at the time of injury

Table 6: Association between Socio-demographic factors and unintentional childhood injuries in rural area $(\mathrm{N}=400)$ and urban area $(\mathrm{N}=500)$ 


\begin{tabular}{|c|c|c|c|c|c|c|c|}
\hline \multirow[b]{3}{*}{ Factor } & \multirow[b]{3}{*}{ Category } & \multirow{2}{*}{\multicolumn{2}{|c|}{$\begin{array}{l}\text { Rural area } \\
95 \% \mathrm{Cl}\end{array}$}} & \multirow[b]{3}{*}{$\begin{array}{l}P \\
\text { value }\end{array}$} & \multicolumn{3}{|l|}{ Urban area } \\
\hline & & & & & \multicolumn{2}{|l|}{$95 \% \mathrm{Cl}$} & \multirow{2}{*}{$\begin{array}{l}P \\
\text { value }\end{array}$} \\
\hline & & OR & $\begin{array}{l}\text { Adjusted } \\
\text { OR }\end{array}$ & & OR & $\begin{array}{l}\text { Adjusted } \\
\text { OR }\end{array}$ & \\
\hline \multirow[t]{5}{*}{ Age } & $<5$ & $\begin{array}{l}3.05(0.9- \\
9.6)\end{array}$ & $\begin{array}{l}3.049(0.92- \\
10.03)\end{array}$ & \multirow{2}{*}{$\begin{array}{l}0.06 \\
0.46\end{array}$} & $\begin{array}{l}1.026(0.384- \\
2.74)\end{array}$ & $\begin{array}{l}1.125(0.40- \\
3.13)\end{array}$ & \multirow{3}{*}{$\begin{array}{l}0.82 \\
0.51 \\
0.69\end{array}$} \\
\hline & $6-10$ & & & & & & \\
\hline & $11-15$ & $\begin{array}{l}1.29(0.43- \\
3.8)\end{array}$ & $\begin{array}{l}1.53(0.48- \\
4.84)\end{array}$ & \multirow[t]{2}{*}{0.82} & $\begin{array}{l}1.22(0.45- \\
3.34)\end{array}$ & $\begin{array}{l}1.40(0.49- \\
3.96)\end{array}$ & \\
\hline & \multirow[t]{2}{*}{$16-18$} & $\begin{array}{l}0.91(0.30- \\
2.7)\end{array}$ & $\begin{array}{l}0.87(0.28- \\
2.75)\end{array}$ & & $\begin{array}{l}1.20(0.45- \\
3.20)\end{array}$ & $\begin{array}{l}1.22(0.45- \\
3.36)\end{array}$ & \\
\hline & & 1 & 1 & & 1 & 1 & \\
\hline \multirow[t]{2}{*}{ Gender } & \multirow{2}{*}{$\begin{array}{l}\text { Male } \\
\text { Female }\end{array}$} & $\begin{array}{l}0.52(0.28- \\
0.95)\end{array}$ & $\begin{array}{l}0.47(0.24- \\
0.90)\end{array}$ & \multirow[t]{2}{*}{0.024} & $\begin{array}{l}0.75(0.47- \\
1.19)\end{array}$ & $\begin{array}{l}0.77(0.48- \\
1.24)\end{array}$ & \multirow[t]{2}{*}{0.28} \\
\hline & & 1 & 1 & & 1 & 1 & \\
\hline \multirow{3}{*}{$\begin{array}{l}\text { Educational } \\
\text { Status of } \\
\text { the } \\
\text { respondent }\end{array}$} & Illiterate & $\begin{array}{l}2.25(0.78- \\
6.4)\end{array}$ & $\begin{array}{l}1.17(0.36- \\
3.76)\end{array}$ & \multirow{3}{*}{$\begin{array}{l}0.78 \\
0.98\end{array}$} & $\begin{array}{l}1.93(0.54- \\
6.85)\end{array}$ & $\begin{array}{l}2.14(0.58- \\
7.91)\end{array}$ & \multirow{3}{*}{$\begin{array}{l}0.25 \\
0.78\end{array}$} \\
\hline & $\begin{array}{l}\text { Upto10th } \\
\text { Std }\end{array}$ & $\begin{array}{l}0.94(0.51- \\
1.7)\end{array}$ & $\begin{array}{l}0.99(0.50- \\
1.9)\end{array}$ & & $\begin{array}{l}0.87(0.52- \\
1.44)\end{array}$ & $\begin{array}{l}0.930(0.55- \\
1.57)\end{array}$ & \\
\hline & $\begin{array}{l}\text { Above } \\
\text { 10Std }\end{array}$ & 1 & 1 & & 1 & 1 & \\
\hline \multirow{2}{*}{$\begin{array}{l}\text { Type of } \\
\text { family }\end{array}$} & & $\begin{array}{l}1.2(0.74- \\
2.12)\end{array}$ & $\begin{array}{l}0.76(0.43- \\
1.34)\end{array}$ & \multirow[t]{2}{*}{0.349} & $\begin{array}{l}1.28(0.81- \\
2.01)\end{array}$ & $\begin{array}{l}1.45(0.89- \\
2.36)\end{array}$ & \multirow[t]{2}{*}{0.13} \\
\hline & $\begin{array}{l}\text { Non- } \\
\text { Nuclear }\end{array}$ & 1 & 1 & & 1 & 1 & \\
\hline \multirow{4}{*}{$\begin{array}{l}\text { Occupation } \\
\text { of father }\end{array}$} & Unemployed & $\begin{array}{l}1.2(0.3- \\
4.9)\end{array}$ & $\begin{array}{l}1.14(0.26- \\
503)\end{array}$ & \multirow{4}{*}{$\begin{array}{l}0.856 \\
0.093\end{array}$} & $\begin{array}{l}1.67(0.34- \\
8.10)\end{array}$ & $\begin{array}{l}1.87(0.36- \\
962)\end{array}$ & \multirow{4}{*}{$\begin{array}{l}0.45 \\
0.91\end{array}$} \\
\hline & Skilled\& & & & & & & \\
\hline & unskilled & $\begin{array}{l}1.61(0.85- \\
3.2)\end{array}$ & $\begin{array}{l}1.86(0.90- \\
3.84)\end{array}$ & & $\begin{array}{l}1.03(0.56- \\
1.89)\end{array}$ & $\begin{array}{l}0.96(0.51- \\
1.81)\end{array}$ & \\
\hline & Profession & 1 & 1 & & 1 & 1 & \\
\hline \multirow{2}{*}{$\begin{array}{l}\text { Occupation } \\
\text { of Mother }\end{array}$} & Homemaker & 1 & 1 & & 1 & 1 & \\
\hline & Others & $\begin{array}{l}0.45(0.23- \\
0.90)\end{array}$ & $\begin{array}{l}0.43(0.20- \\
0.90)\end{array}$ & 0.027 & $\begin{array}{l}1.05(0.56- \\
1.97)\end{array}$ & $\begin{array}{l}0.97(0.50- \\
1.87)\end{array}$ & 0.94 \\
\hline \multirow{3}{*}{$\begin{array}{l}\text { Socio- } \\
\text { economic } \\
\text { status }\end{array}$} & Upper class & 1 & 1 & & 1 & 1 & \\
\hline & $\begin{array}{l}\text { Middle } \\
\text { class }\end{array}$ & $\begin{array}{l}0.68(0.28- \\
1.6)\end{array}$ & $\begin{array}{l}0.64(0.24- \\
1.74)\end{array}$ & \multirow{2}{*}{$\begin{array}{l}0.38 \\
0.611\end{array}$} & $\begin{array}{l}2.53(0.86- \\
7.44)\end{array}$ & $\begin{array}{l}0.29(0.10- \\
0.89)\end{array}$ & \multirow{2}{*}{$\begin{array}{l}0.03 \\
0.04\end{array}$} \\
\hline & Lower class & $\begin{array}{l}0.82(0.34- \\
2.00)\end{array}$ & $\begin{array}{l}0.77(0.28- \\
2.07)\end{array}$ & & $\begin{array}{l}0.84(0.53- \\
1.34)\end{array}$ & $\begin{array}{l}0.32(0.10- \\
0.98)\end{array}$ & \\
\hline \multirow[t]{2}{*}{ Sibling } & No & \multirow{2}{*}{$\begin{array}{l}1.57(0.66- \\
3.72)\end{array}$} & $\begin{array}{l}1.10(0.41- \\
293)\end{array}$ & 0.84 & $1(0.49-2.02)$ & $\begin{array}{l}0.97(0.47- \\
0.03)\end{array}$ & 0.95 \\
\hline & 1 & & & 0.73 & & & 0.01 \\
\hline
\end{tabular}


$\geq 2$

$1.04(0.58-$

1.89)

$0.89(0.46-$

$0.623(0.38-$

$0.53(0.31-$

Legend: ${ }^{b}$ Non-Nuclear family includes Joint family and Three generation family

Table 7: Description of environmental risk factors of unintentional injuries among study participants in rural and urban area 


\begin{tabular}{|c|c|c|c|c|c|c|}
\hline \multirow[b]{3}{*}{ Factors } & \multicolumn{3}{|c|}{ Rural area } & \multicolumn{3}{|c|}{ Urban area } \\
\hline & \multirow[b]{2}{*}{$\mathrm{n}^{* *}$} & \multicolumn{2}{|c|}{ Frequency (\%) } & \multirow[b]{2}{*}{$n^{* *}$} & \multicolumn{2}{|c|}{ Frequency (\%) } \\
\hline & & Present & Absent & & Present & Absent \\
\hline \multicolumn{7}{|l|}{ Road traffic injuries } \\
\hline 1. Protective gears by & 209 & 166(79.4) & $43(20.6)$ & 309 & $234(75.7)$ & $75(24.3)$ \\
\hline Hangof mohilo & 229 & $54(23.6)$ & $175(76.4)$ & 304 & $79(26)$ & $225(74)$ \\
\hline 2. Usage or modile wnile ariving & 243 & $34(14)$ & $209(86)$ & 320 & $34(10.6)$ & $286(89.4)$ \\
\hline $\begin{array}{l}\text { 4. Child unattended while walking on } \\
\text { road }\end{array}$ & 346 & $51(14.7)$ & $295(85.3)$ & 413 & $56(13.6)$ & $357(86.4)$ \\
\hline \multicolumn{7}{|l|}{ Burn } \\
\hline 1. Storage of flammable substance & 361 & $124(34.3)$ & $237(65.7)$ & 491 & $141(28.7)$ & $350(71.3)$ \\
\hline No cenaration of conking area & 384 & $117(30.5)$ & $267(69.5)$ & 494 & 107(21.7) & $387(78.3)$ \\
\hline from living area & 372 & 123(33.1) & $249(66.9)$ & 483 & $149(30.8)$ & $334(69.2)$ \\
\hline 3. Stove within reach of child & 366 & $51(13.9)$ & $315(86.1)$ & 480 & $24(5)$ & $456(95)$ \\
\hline \multicolumn{7}{|l|}{$\begin{array}{l}\text { 4. Open fire/fire place within reach of } \\
\text { child }\end{array}$} \\
\hline \multicolumn{7}{|l|}{ Fall } \\
\hline 1. Unprotected roof/balcony/stair & 351 & $86(24.5)$ & $265(75.5)$ & 492 & $108(22)$ & $384(78)$ \\
\hline $\begin{array}{l}\text { 2. Unsafe equipment/deep ditches in } \\
\text { playground }\end{array}$ & 343 & $92(26.8)$ & $251(73.2)$ & 487 & $71(14.6)$ & $416(85.4)$ \\
\hline \multicolumn{7}{|l|}{ Sharp injury } \\
\hline 1. Sharp objects within child's reach & 361 & $68(18.8)$ & 293(81.2) & 490 & 77(15.7) & $413(84.3)$ \\
\hline \multicolumn{7}{|l|}{ Animal bite } \\
\hline 1. Presence of animal at home & 383 & 116(30.3) & $267(69.7)$ & 498 & 73(14.7) & $425(85.3)$ \\
\hline 2. Interaction with animals & 391 & $111(28.4)$ & $280(71.6)$ & 493 & $48(9.7)$ & $445(90.3)$ \\
\hline
\end{tabular}

Legend: * Factors are assessed based on possibility of exposure to risk factors due to several factors such as transportation system, mobility of child, age of the child etc.

Table 8: Association between fall and risk factor for fall among children with unintentional in rural and urban area 


\begin{tabular}{|c|c|c|c|c|c|c|c|}
\hline \multicolumn{3}{|c|}{ Factors } & \multicolumn{2}{|l|}{ Fall } & \multirow[b]{2}{*}{$\begin{array}{l}P \\
\text { value }\end{array}$} & \multirow[b]{2}{*}{ OR } & \multirow[b]{2}{*}{$\begin{array}{l}P \\
\text { value }\end{array}$} \\
\hline & & & Yes & No & & & \\
\hline \multirow{6}{*}{$\begin{array}{l}\text { Rural } \\
\text { area }\end{array}$} & \multirow{2}{*}{$\begin{array}{l}\text { Unprotected } \\
\text { roof/balcony/Staircase } \\
(n=351)\end{array}$} & Yes & 16(18.6) & 70(81.4) & \multirow[t]{2}{*}{$0.01^{9}$} & \multirow{2}{*}{$\begin{array}{l}2.29(1.15- \\
4.55)\end{array}$} & \multirow[t]{2}{*}{$0.01^{9}$} \\
\hline & & No & $24(9.1)$ & 241(90.9) & & & \\
\hline & $\begin{array}{l}\text { Unsafe equipment/ Deep } \\
\text { ditches in playground }\end{array}$ & & & & & & \\
\hline & \multirow{3}{*}{$(n=343)$} & Yes & 16(17.4) & 76(82.6) & \multirow{3}{*}{$0.04^{9}$} & $199(100-$ & \multirow{3}{*}{$0.04^{9}$} \\
\hline & & No & $24(9.6)$ & 227(90.4) & & $3.94)$ & \\
\hline & & & & & & 1 & \\
\hline \multirow{5}{*}{$\begin{array}{l}\text { Urban } \\
\text { area }\end{array}$} & \multirow{2}{*}{$\begin{array}{l}\text { Unprotected } \\
\text { roof/balcony/staircase } \\
(n=492)\end{array}$} & Yes & 19(17.6) & $89(82.4)$ & \multirow{2}{*}{$0.02^{9}$} & $\begin{array}{l}2.00(1.09- \\
364)\end{array}$ & \multirow[t]{2}{*}{$0.02^{9}$} \\
\hline & & No & $37(9.6)$ & $347(90.4)$ & & & \\
\hline & \multirow[t]{3}{*}{$\begin{array}{l}\text { Unsafe equipment/deep } \\
\text { ditches in playground }(n=487)\end{array}$} & Yes & $23(32.4)$ & $48(67.6)$ & \multirow{3}{*}{$0.00^{9}$} & & \multirow{3}{*}{$0.00^{9}$} \\
\hline & & \multirow[t]{2}{*}{ No } & \multirow[t]{2}{*}{$33(7.9)$} & \multirow[t]{2}{*}{$383(92.1)$} & & $10.24)$ & \\
\hline & & & & & & 1 & \\
\hline
\end{tabular}

Legend: $* \star * ~ p$ value $<0.05$ and is statistically significant

\section{Figures}




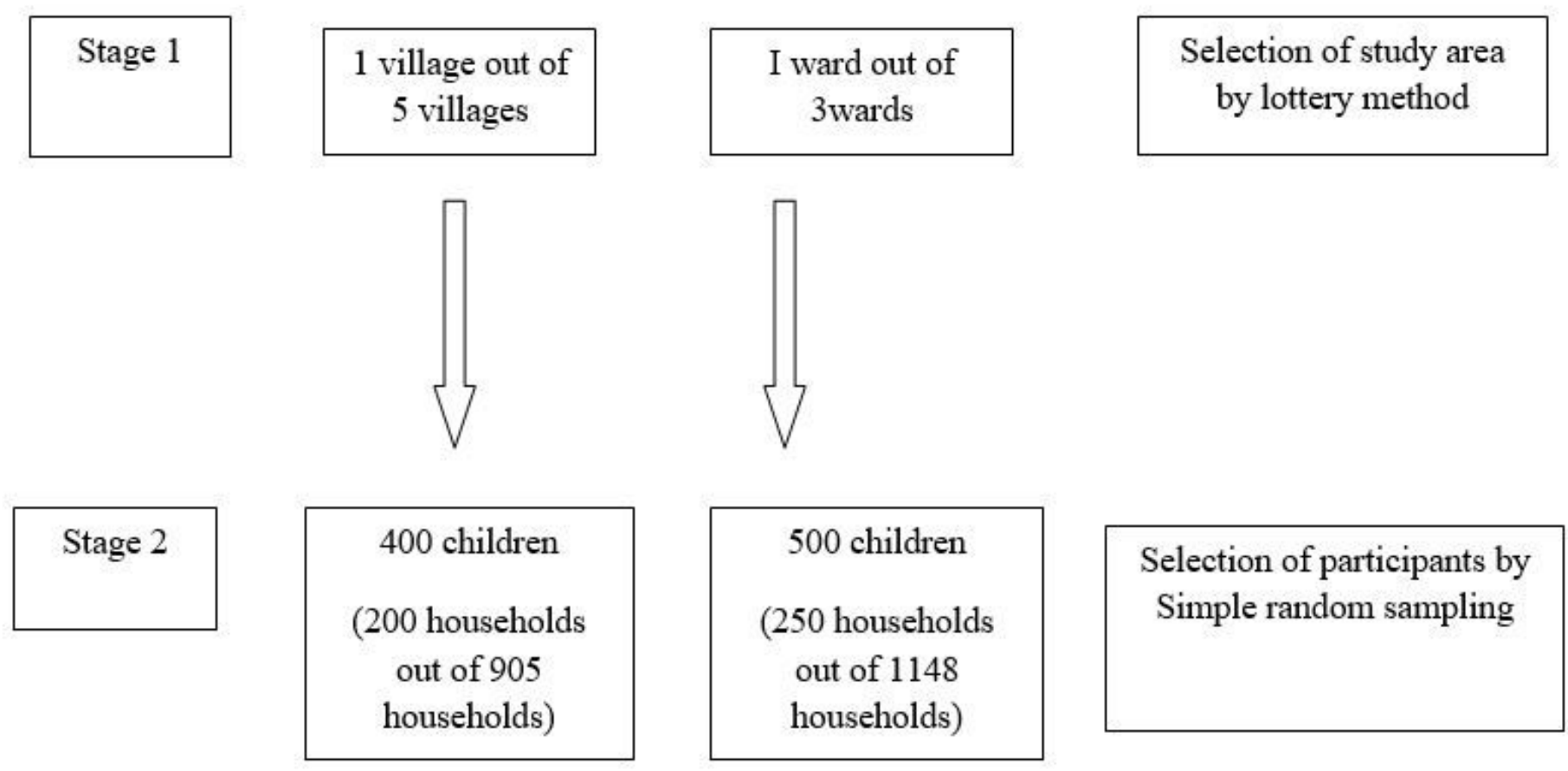

\section{Figure 1}

Flowchart of households and number of participants who were enrolled for study in urban and rural area

Legend: One village and 1 ward are selected by lottery method at first stage. In the second stage, Simple random sampling method is followed to select study participants in both areas 